\title{
Multi-Year Pathogen Survey of Biofuel Switchgrass Breeding Plots Reveals High Prevalence of Infections by Panicum mosaic virus and Its Satellite Virus
}

\author{
Catherine L. Stewart, Jesse D. Pyle, Charlene C. Jochum, Kenneth P. Vogel, Gary Y. Yuen, and Karen-Beth G. Scholthof \\ First, third, and fifth authors: Plant Pathology Department, University of Nebraska-Lincoln, 406 Plant Sciences Hall, Lincoln 68583-0722; \\ second and sixth authors: Department of Plant Pathology \& Microbiology, Texas A\&M University, College Station 77843; and fourth author: \\ Agricultural Research Service, USDA \& Department of Agronomy \& Horticulture, University of Nebraska-Lincoln, 137 Keim Hall, \\ Lincoln 68583-0937.
}

Accepted for publication 7 April 2015.

\begin{abstract}
Stewart, C. L., Pyle, J. D., Jochum, C. C., Vogel, K. P., Yuen, G. Y., and Scholthof, K.-B. G. 2015. Multi-year pathogen survey of biofuel switchgrass breeding plots reveals high prevalence of infections by Panicum mosaic virus and its satellite virus. Phytopathology 105:1146-1154.

Switchgrass (Panicum virgatum) cultivars are currently under development as lignocellulosic feedstock. Here we present a survey of three established switchgrass experimental nurseries in Nebraska in which we identified Panicum mosaic virus (PMV) as the most prevalent virus. In $2012,72 \%$ of 139 symptomatic plants tested positive for PMV. Of the PMV-positive samples, $19 \%$ were coinfected with its satellite virus (SPMV). Less than $14 \%$ of all sampled plants in 2012 were positive

for four additional viruses known to infect switchgrass. In 2013, randomized sampling of switchgrass individuals from the same 2012 breeding plots revealed that infection by PMV or PMV+SPMV was both more prevalent and associated with more severe symptoms in the cultivar Summer, and experimental lines with Summer parentage, than populations derived from the cultivar Kanlow. A 3-year analysis, from 2012 to 2014, showed that previously uninfected switchgrass plants acquire PMV or PMV+SPMV between harvest cycles. In contrast, some plants apparently did not maintain PMV infections at detectable levels from year-to-year. These findings suggest that PMV and SPMV should be considered important pathogens of switchgrass and serious potential threats to biofuel crop production efficiency.
\end{abstract}

In the past decade, public and private efforts have focused on developing high lignocellulosic biomass crops as feedstock for generation of biofuels (McLaughlin and Kszos 2005; Perry 2012; Somma et al. 2010). One promising North American crop is switchgrass (Panicum virgatum $\mathrm{L}$.), a warm-season $\mathrm{C}_{4}$ perennial grass native to the region east of the Rocky Mountains (Vogel 2004; McLaughlin and Kszos 2005). Switchgrass is a high yielding perennial biomass plant that can be grown on marginal cropland with total net energy production outputs of more than $500 \%$ of total resource input (Bouton 2007; Hill et al. 2006; Sanderson et al. 1996; Schmer et al. 2008). In terms of biofuel production, cultivated switchgrass is estimated to match current ethanol yields derived from maize, and will likely exceed these production amounts as switchgrass cultivation, development, and processing technologies continue to advance and develop (Bouton 2007; Schmer et al. 2008).

The emergence of pathogens in newly established switchgrass agroecosystems, and concomitant production losses, is a matter of concern for plant pathologists, plant breeders, and agronomists. Current switchgrass cultivars deployed in the field for forage and erosion control are typically described as tolerant to or unaffected by most types of microbial pathogens (Bouton 2007; Vogel 2004), yet our knowledge of pathogens of switchgrass is limited. Several species of plant-pathogenic fungi including Bipolaris oryzae (leaf spot), B. spicifera (spot blotch and root rot), Colletotrichum graminicola (leaf spot), C. navitas (anthracnose), Elsinoe panici

Corresponding author: K.-B. G. Scholthof; E-mail address: kbgs@tamu.edu

*The $\boldsymbol{e}$-Xtra logo stands for "electronic extra" and indicates that one supplementary figure and three supplementary tables are published online.

http://dx.doi.org/10.1094/PHYTO-03-15-0062-R

This article is in the public domain and not copyrightable. It may be freely reprinted with customary crediting of the source. The American Phytopathological Society, 2015. (leaf spot), Puccinia emaculata (rust), Rhizoctonia cerealis (sharp eyespot), Tilletia pulcherrima (bunt), and Uromyces graminicola (rust) have been isolated and identified as disease-causing agents of switchgrass (Carris et al. 2008; Crouch et al. 2009; Etheridge et al. 2001; Krupinsky et al. 2004; Tiffany and Knaphus 1995; Uppalapati et al. 2013; Vu et al. 2011). Thus far, confirmed reports of plantpathogenic bacteria and nematodes of switchgrass are limited or circumstantial (Cassida et al. 2005; Mekete et al. 2010). The absence of field pathogenicity surveys of microbial pathogens on switchgrass hosts indicates that their potential impact on switchgrass production efficiency remains undetermined.

Plant viruses comprise another pathogen group for which little information is available as to their occurrence and importance in switchgrass. Members of the family Luteoviridae, including Barley yellow dwarf virus (BYDV, genus Luteovirus) and Cereal yellow dwarf virus (CYDV, genus Polerovirus) have been identified as pathogens of switchgrass (Garrett et al. 2004). BYDV and CYDV are positive-sense, single-stranded RNA (+ssRNA) viruses that rely on aphid vectors for plant-to-plant transmission. Multiple strains of these viruses have been identified and characterized by their strainspecific association with key aphid vectors. BYDV strains MAV and PAV and CYDV strain RPV are known pathogens of switchgrass in the field and rely on persistent transmission by multiple species of aphid vectors including the grain aphid (Sitobion avenae), the bird cherry-oat aphid (Rhopalosiphum padi), and rose grain aphid (Metopolophium dirhodum) (Garrett et al. 2004; Gray and Gildow 2003). Additional +ssRNA viruses of switchgrass include Sugarcane mosaic virus (SCMV, genus Potyvirus) and Switchgrass mosaic virus (SwMV, putative genus Marafivirus) (Agindotan et al. 2010, 2013b). Recently, high-throughput sequencing analyses indicated the presence of partial sequences related to eight RNA viruses and one DNA virus in diverse families (Agindotan et al. 2013a). Together, these studies suggest that pathogenic viruses of switchgrass are likely present in the field, but their prevalence in 
cultivated switchgrass and their impact on switchgrass growth are largely unknown.

Panicum mosaic virus (PMV) was discovered in Kansas in 1953 and described as the first viral pathogen of switchgrass (Sill and Pickett 1957). PMV also infects St. Augustinegrass (Stenotaphrum secundatum), a turfgrass, causing St. Augustine decline disease, as first reported in the early 1960s (Batten and Scholthof 2004). PMV infects residential St. Augustinegrass lawns in states along the Gulf Coast region of the United States and, recently, in New South Wales, Australia (Batten and Scholthof 2004; Thomas and Steele 2011). PMV has also been identified in Oklahoma, Kansas, Nebraska, Wisconsin, North Carolina, and South Carolina. In addition to switchgrass and St. Augustinegrass, PMV infects pearl (Pennisetum glaucum), proso (Panicum miliaceum), and foxtail (Setaria italica) millets; maize (Zea mays); centipedegrass (Eremochloa ophiuroides); and crabgrass (Digitaria sanguinalis) (Batten and Scholthof 2004). Experimental model hosts of the virus include Brachypodium distachyon (Brachypodium) and Setaria viridis (Setaria) (Mandadi and Scholthof 2012; Mandadi et al. 2014).

PMV is a +ssRNA virus and the type member of the genus Panicovirus in the family Tombusviridae (Turina et al. 1998, 2000). The 4,326 nucleotide genomic RNA is encapsidated by a $26-\mathrm{kD}$ capsid protein $(\mathrm{CP})$ to form $30 \mathrm{~nm}$ icosahedral virions. An unusual feature of PMV is that the virus supports the accumulation of a satellite virus (SPMV) (Masuta et al. 1987; Scholthof 1999; Turina et al. 1998). SPMV, an 826 nucleotide +ssRNA, encodes a 17.5-kDa $\mathrm{CP}$ that is assembled into $16 \mathrm{~nm}$ icosahedral virions. By definition, a satellite virus like SPMV is dependent on its helper virus (PMV) for replication and systemic movement in the host plant. The mixed infection of PMV+SPMV is characterized by exacerbated host symptoms and more rapid systemic accumulation of the viruses than observed during infections by PMV alone (Mandadi and Scholthof 2012; Scholthof 1999). Despite the observed severity and prevalence of this pathosystem in St. Augustinegrass and the significant overlap in the geographic distributions of PMV and cultivated switchgrass, there have been no reports or surveys investigating the emergence of the PMV disease complex in switchgrass populations.

Because cropping systems for switchgrass as a biofuel are still being developed, comprehensive pathogen surveys are required in order to proactively assess the potential pathogen-associated threats to large-scale production. Here we report on plant viruses present in three previously established genetic and breeding experimental field nurseries in eastern Nebraska. The nurseries were designed prior to this survey to aid in the development and ultimate release of bioenergy switchgrass cultivars. A pathogenicity assessment in these established experimental fields was performed to determine potential cultivar-specific pathogen problems, which may inform future decisions regarding the selection of optimum switchgrass cultivar for lignocellulosic feedstock. Findings from this 3-year study, from 2012 to 2014, identified PMV and PMV+SPMV as the most prevalent infection types in experimental switchgrass populations. Additionally, this viral disease complex was consistently associated with enhanced field symptomatology in susceptible switchgrass populations.

\section{MATERIALS AND METHODS}

Establishing and maintaining switchgrass breeding nurseries. Switchgrass plants for the field nurseries were established from greenhouse-grown switchgrass seedlings with a $16 \mathrm{~h}$ light $/ 8 \mathrm{~h}$ dark photoperiod. The seedlings were grown in Ray Leach SC7 Cone-tainers (Steuwe \& Sons, Inc., Tangent, OR) in a $1: 1: 1$ potting mixture of loam soil/peat/perlite by volume. Switchgrass plants at the two to three leaf stage were transplanted into each respective experimental field plot.

The field plots were located at the University of Nebraska Agricultural Research and Extension Center located near Mead,
NE $\left(41.166103^{\circ} \mathrm{N}, 96.482938^{\circ} \mathrm{W}\right)$. These nurseries were PV0910, PV1103, and PV1104 with PV indicating P. virgatum (switchgrass), the first two numbers indicating the establishment year and the following two numbers indicating the sequential experiment number for that year. Field nurseries PV1103 and PV1104 were adjacent to one another in an area located approximately $2 \mathrm{~km}$ from PV0910. The three fields contained transplanted switchgrass plants grown in rows spaced $1.1 \mathrm{~m}$ apart. In PV0910, plants within rows were also spaced $1.1 \mathrm{~m}$ apart. In PV1103 and PV1104, plants in half-sib families or check strain plots were spaced $0.5 \mathrm{~m}$ apart. The switchgrass cultivars, experimental strains, and half-sib families that were in these fields are summarized in Supplementary Table S1. Each of the five cultivars or experimental strains in experiment PV0910 was treated as a distinct population. All of the plants in PV1103 were considered to be a single population in this study, as were all plants in PV1104.

Within the PV0910 field, soil between plants and rows were cultivated with 0.6 -m-wide roto-tillers creating mini-plots $(0.4 \mathrm{~m} \times 0.4 \mathrm{~m})$ containing individual plants. In PV1103 and PV1104, roto-tillers were used between rows and hand weeding was used between plants within a plot. Nurseries were fertilized annually with $112 \mathrm{~kg}$ of $\mathrm{N}$ per ha. In addition to tillage, the following herbicide mixture was applied to the field nurseries post-transplanting and annually each spring: metolachor (2-chloro-N-(2-ethyl-6methylphenyl)-N-(2methoxy-1-methyl)acetamide), atrazine (6-chloro-N-ethyl-N-isopropyl1,3,5,-triazine-2,4-diamine), and 2,4-D (2,4-dichlorophenoxyacetic acid) at $1.1,2.2$, and $1.1 \mathrm{~kg}$ ai/ha, respectively. All nurseries were harvested in 2012 and PV1103 and PV1104 were also harvested in 2013. Harvests were made after a killing frost with a flail type forage plot harvester. In years when plants were not harvested in the fall, the nurseries were mowed or burned each spring to remove the accumulated biomass from the previous year.

Field survey and sampling techniques. A preliminary inspection of established switchgrass nurseries was conducted in May 2012. From this initial inspection, three nurseries were identified with noticeable symptoms suggestive of virus infection. These nurseries were subsequently inspected and sampled during the 2012, 2013, and 2014 seasons. In 2012, inspection and sampling of symptomatic plants in PV1103 and PV1104 (1-year-old nurseries) and PV0910 (a 3-year-old nursery), was conducted to assess virus symptom incidence and severity and for diagnosis of the causal agent(s). To provide a measure for the degree of symptom expression, we developed a visual disease severity rating (DSR) in which a 1 to 5 score was assigned to each plant based on a subjective scale of chlorotic mottling or mosaic of the foliage tissues and stunting of plants (Table 1). Each sample was placed in a plastic bag and kept on ice for transport to the University of Nebraska-Lincoln campus where the samples were stored at $-20^{\circ} \mathrm{C}$ while processing plant material, and at $-75^{\circ} \mathrm{C}$ for long-term storage.

In 2013, the second year of this study, randomly selected plants from plots PV0910, PV1103, and PV1104 were sampled to determine the incidence of infection by PMV alone and coinfections by PMV+SPMV, and if there were any relationships between virus infection, switchgrass cultivar/strain, and symptom severity. More than 50 plants were selected at random from each of the five populations in experiment PV0910 (over 250 plants total).

TABLE 1. Disease severity rating (DSR) system for virus symptoms on switchgrass plants

\begin{tabular}{ll}
\hline DSR & Associated disease characteristics \\
\hline 1 & No visual symptoms associated with viral infection \\
2 & Indistinct mottling or mosaic, or distinct mottling or \\
mosaic in less than $10 \%$ of the canopy \\
3 & Distinct mottling or mosaic in greater than $10 \%$ but less \\
than $50 \%$ of the canopy \\
4 & Distinct mottling or mosaic in over $50 \%$ of the canopy \\
5 & Distinct mottling or mosaic in over $50 \%$ of the canopy, \\
& with additional stunting \\
\hline
\end{tabular}


Similarly, over 50 plants were identified randomly from each of experiments PV1103 and PV1104, with the plants in each of these two experiments representing single, distinct populations. Sampling and symptom severity scoring was performed for all three fields during the summer months, from May to August.

Field samples were obtained by grasping and tearing two to three leaves (ca. $15 \mathrm{~cm}$ tissue) at random from the top portion of the plant. There was no attempt to select leaves based on observable symptoms. All leaves from a single sampling event for each individual plant were pooled together, representing one sample for processing. Data from each experiment or switchgrass population were analyzed separately to investigate the relationships between virus presence and disease symptom severity. Two methods of analysis were used, the first being the calculation of the percentages of plants with no virus, PMV alone, or PMV+SPMV among plants within a DSR category (1 to 5). In the second method, a mean DSR was calculated from all plants within a virus category. Because of the disparity in number of measurements used in calculating mean DSR values, ProcMixed (SAS 9.3, SAS Institute, Cary, NC) was used in means comparison by generating least squares means (ls-means) and testing differences among ls-means for statistical significance.

Three sets of plants were selected for two rounds of targeted resampling in 2013 and 2014 to investigate changes in virus presence from one year to the next. In this instance, resampling refers to plants that were sampled the preceding year (2012 and/or 2013). The absence or presence of PMV and SPMV in plants resampled in 2013 and 2014 was determined previously during the 2012 and 2013 growing seasons, respectively. In 2013 a set consisted of 27 plants resampled from nurseries PV1103 and PV1104. In 2014 a set of 24 plants was resampled from PV1103 and PV1104. A third set, also collected in 2014, consisted of 51 plants resampled from Summer and Kanlow $\times$ Summer $(\mathrm{K} \times \mathrm{S})$ populations in experiment PV0910.

Serological virus detection from switchgrass samples. Switchgrass leaf samples collected in 2012 were analyzed using double-antibody sandwich enzyme-linked immunosorbent assay (DAS-ELISA) kits (AC Diagnostics, Fayetteville, AR) specific for PMV, SCMV, Wheat streak mosaic virus (WSMV), CYDVRPV, and BYDV-MAV and -PAV serotypes. In 2013 and 2014, DAS-ELISA was used to assay switchgrass samples for PMV. For DAS-ELISA, leaf tissue was ground in a 1:10 ratio with the manufacturer-provided sample buffer containing phosphatebuffered saline $(10 \mathrm{mM}$ sodium phosphate, $\mathrm{pH} 7.5,0.15 \mathrm{M} \mathrm{NaCl}$ [PBS] with $0.05 \%$ Tween-20 [PBST]), and the extracts tested in duplicate wells following methods specified by the manufacturer. One hour after adding the substrate, optical density (OD) readings were taken at $405 \mathrm{~nm}$. Negative controls included the negative control supplied in the DAS-ELISA kits and tissue extracts from two switchgrass seedlings cultivated in a growth chamber. All field and control samples were replicated at least twice for each ELISA plate. A negative-positive threshold was calculated for each plate from the average negative control OD values, plus two standard deviations from the mean. If a sample produced reactions in both of its wells that exceeded the negative-positive threshold, the sample was considered to be positive for the serological presence of the corresponding virus. Most of the samples were well above (positive reading) or well below (negative reading) the established negativepositive threshold. Samples with reactions that varied considerably between duplicate wells or which exhibited reactions close to the negative-positive threshold were retested by PMV-specific DASELISA or by reverse transcription-polymerase chain reaction (RT-PCR).

All samples collected in 2012 that were positive for PMV in DASELISA were retested for PMV and SPMV by immunoblot analyses as described previously (Mandadi et al. 2014). Tissue samples previously homogenized in PBST were centrifuged at $10,000 \times g$ for $5 \mathrm{~min}$. The supernatants containing soluble proteins were mixed in a 1:1 ratio with $5 \times$ Laemmli total protein extraction buffer. The prepared samples were boiled for $5 \mathrm{~min}$, separated on $12.5 \%$ polyacrylamide-sodium dodecyl sulfate gels by electrophoresis (SDS-PAGE) (Bio-Rad, Hercules, CA), then transferred to nitrocellulose membranes. Membranes were incubated in blocking solution (5\% milk in Tris-buffered saline [TBS] [10 mM Tris, $\mathrm{pH}$ 7.4 , and $0.15 \mathrm{M} \mathrm{NaCl}$ ] plus $0.05 \%$ Tween-20 [TBST]) for $1 \mathrm{~h}$ at $25^{\circ} \mathrm{C}$ on a shaker, then incubated with primary rabbit polyclonal antibody solutions for either PMV (1:5,000 dilution) or SPMV $(1: 2,000$ dilution $)$ in blocking solution overnight at $4^{\circ} \mathrm{C}$. Following incubation with the primary antibody, the membranes were washed three times on a shaker: one quick rinse with TBST, two $5 \mathrm{~min}$ washes at $25^{\circ} \mathrm{C}$ in TBST. Next, the membranes were incubated at $25^{\circ} \mathrm{C}$ with the horseradish peroxidase (HRP)-conjugated goat antirabbit secondary antibody (Thermo Scientific) (1:10,000 dilution) in blocking solution. Membranes were then rinsed with TBST and washed for $5 \mathrm{~min}$ in $\mathrm{TBST}$ at $25^{\circ} \mathrm{C}$, rinsed in TBS, and then developed using ECL Prime chemiluminescent reagents (Amersham) and exposed to X-ray film (Agfa).

RNA extraction and RT-PCR analysis. Total RNA was extracted from leaf samples using the Direct-zol RNA MiniPrep kit (Zymo Research, Irvine, CA) and TRI reagent (Ambion, Grand Island, NY). The homogenized PBST switchgrass leaf tissue samples prepared for DAS-ELISA also was suitable for total RNA isolation. For the initial phenol extraction, $50 \mu \mathrm{l}$ of leaf sample homogenate was combined with $400 \mu \mathrm{l}$ of the TRI reagent. All steps following the TRI reagent extraction were conducted according to the manufacturer's protocol. RNA quality was visually assessed by electrophoresis on a $1 \%$ agarose gel and ethidium bromide staining. Total cDNA was prepared using SuperScript III Reverse transcription (Life Technologies, Grand Island, NY) as described by the manufacturer. All first-strand cDNA synthesis reactions were primed with either the reverse SPMV or PMV primers. The generated cDNA samples were used as templates in PCR using Taq DNA polymerase. The primers used for RT-PCR diagnostics of PMV and SPMV were specific for the open reading frames of the PMV CP (forward primer: 5' -ATGAATCGCAATGGAGCTAC-3';

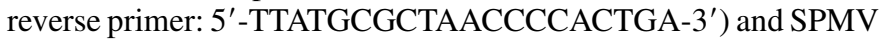
CP (forward primer: 5' -ATGGCTCCTAAGCGTTCCA-3'; reverse primer: 5'-TTATGAAGACTGAAGCTCGC-3').

\section{RESULTS}

Prevalence and distribution of virus-associated symptoms in switchgrass breeding plots in 2012. Typical virus-like symptoms observed on switchgrass plants in the field included mild to severe chlorotic mottling or mosaic of the foliage, as well as stunting of most or all tillers of individual plants (Fig. 1). Surprisingly, nearly $60 \%$ of the switchgrass populations in the two experiments PV1103 and PV1104, each containing more than 1700 plants of a single population, were symptomatic (Table 2). Of the plants in the PV1103 and PV1104 nurseries, 12 and 24\%, respectively, exhibited high disease severity ratings (DSR 4 or 5).

In contrast, disease incidence varied markedly among the five switchgrass populations in experiment PV0910, each with roughly 300 plants. The highest disease incidence (69\%) was found in Summer, whereas Kanlow and the two Kanlow-derived populations (Kanlow N1 and Kanlow High Yield) exhibited disease incidences of approximately $20 \%$. Incidences of plants with a DSR of 4 or 5 also differed between Summer $(20 \%)$ and the Kanlow-derived populations $(<1 \%)$. The $\mathrm{K} \times \mathrm{S}$ population, based on crosses between Kanlow and Summer, from PV0910 was intermediate between that of the Summer and the Kanlow germplasm populations, with respect to total disease incidence and the incidence of plants with high to severe symptoms. Despite the high percentage of symptomatic plants, there were no obvious visual spatial patterns for symptomatic individuals or for symptom severity within a population. A representative example of the distribution of 
symptomatic individuals and the associated DSRs is illustrated for a portion of field PV1104 (Supplementary Fig. S1). Together, these results reveal that virus-associated symptoms, such as chlorotic mottling, mosaic, and stunting were highly prevalent among individuals in the switchgrass experimental fields, particularly in certain switchgrass populations.

Detection of viruses in switchgrass samples. With the high incidence of virus-associated symptoms observed in 2012 in the switchgrass experiments, we next sought to identify potential causal agents. In total, 139 individual plants were sampled and analyzed via DAS-ELISA for BYDV-MAV, BYDV-PAV, CYDV-RPV, PMV, SCMV, and WSMV. Of the samples collected, 72\% (100 samples) were positive for PMV alone or in combination with other viruses (Table 3). Four other viruses were detected in 14\% (19 samples) of all samples tested. Additionally, 24\% (33 samples) did not give a positive ELISA reaction for the tested viruses. WSMV was not detected in any samples by DAS-ELISA.

Subsequent immunoblot analyses of the 109 PMV-positive samples revealed that 19 (14\% of the total samples) were also positive for SPMV (PMV+SPMV). Of these, 4 contained a third virus. From the ELISA results, 9 PMV-infected plants (6\% of all samples) were coinfected with viruses other than SPMV. Overall, these results demonstrate that PMV, alone or in a coinfection with SPMV or with other unrelated viruses, was the predominant virus detected among symptomatic switchgrass samples in the experimental fields in 2012.

PMV and SPMV incidence in 2013. During the 2013 harvest cycle, the same experimental fields that were surveyed in 2012 (PV1103, PV1104, and PV0910) were assessed for PMV and PMV+SPMV incidence. We used leaf tissue from plants selected randomly, without regard to symptomology. PMV was assayed by DAS-ELISA. Samples that were negative by ELISA were retested for PMV by RT-PCR. All PMV-positive samples were tested for SPMV by RT-PCR. Of 56 plants sampled from PV1103, 2 (4\%) tested positive for PMV alone, 27 (48\%) tested positive for PMV+SPMV, and $26(46 \%)$ were negative for PMV (Fig. 2 and Supplementary Table S2). Of 53 plants sampled from
PV1104, none were positive for PMV alone, 41 samples (76\%) had both PMV and SPMV, and 12 (23\%) of the plants tested negative for PMV.

Experimental field PV0910 contained five switchgrass populations planted in three clonal replicate blocks, each replicate block contained genetically identical plants to the other replicates. This field provided us with an opportunity to determine if specific populations being developed for desirable bioenergy traits differed in susceptibility to infection by PMV alone or the coinfection of PMV+SPMV. It is not known whether selective breeding measures have an impact on host susceptibility or tolerance to pathogens. To evaluate this, more than 50 plants in each population were randomly

TABLE 3. Incidences of single- and multiple-virus infections among symptomatic switchgrass plants sampled in $2012^{\mathrm{a}}$

\begin{tabular}{lcc}
\hline Virus(es) detected & $\begin{array}{c}\text { Number of } \\
\text { plants }\end{array}$ & $\begin{array}{c}\text { Percentage of } \\
\text { total plants tested }\end{array}$ \\
\hline No virus detected & 33 & $24 \%$ \\
Single virus detected & 72 & $52 \%$ \\
PMV & 3 & $2 \%$ \\
CYDV-RPV & 2 & $1 \%$ \\
SCMV & 1 & $1 \%$ \\
BYDV-MAV & 15 & $11 \%$ \\
Multiple viruses detected & 2 & $1 \%$ \\
PMV+SPMV & 1 & $1 \%$ \\
PMV+SPMV+SCMV & 1 & $1 \%$ \\
PMV+SPMV+CYDV-RPV & 4 & $3 \%$ \\
PMV+SPMV+BYDV-PAV & 2 & $1 \%$ \\
PMV+SCMV & 2 & $1 \%$ \\
PMV+CYDV-RPV & 1 & \\
PMV+CYDV-RPV+SCMV & & \\
PMV+BYDV-PAV & &
\end{tabular}

a Each of 139 samples were tested by DAS ELISA for the presence of Panicum mosaic virus (PMV), Barley yellow dwarf virus strains MAV and PAV (BYDVMAV, -PAV), Cereal yellow dwarf virus strain RPV (CYDV-RPV), and Sugarcane mosaic virus (SCMV). Only PMV-positive samples were tested for the presence of its satellite virus (SPMV) by immunoblot analysis.
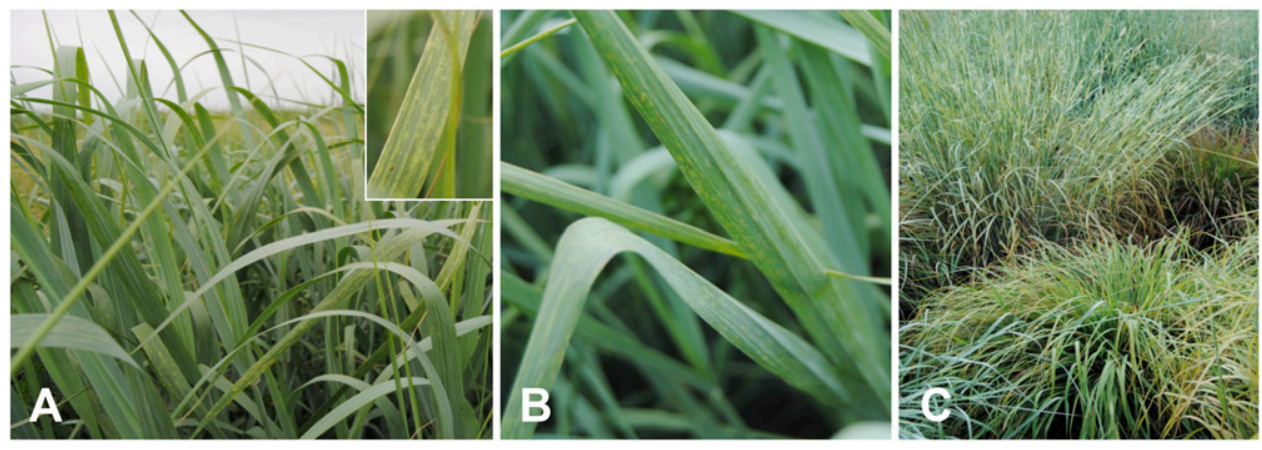

Fig. 1. Virus-like symptoms in switchgrass populations in 2012. Chlorotic mottling and mosaic symptoms were frequently observed on switchgrass canopy tissues, as shown on the foliage of A, Kanlow and B, Kanlow N1 individuals. The inset image in A depicts the chlorotic mosaic pattern from an individual of the Kanlow population. Typical stunting of aboveground portions of plants associated with virus infection were also prominent, as shown for $\mathbf{C}$, an individual of the Kanlow variety, seen in the picture foreground, compared with a Kanlow plant with normal growth in the background.

TABLE 2. Incidence of virus-associated symptoms in switchgrass populations in Nebraska field experiments in 2012

\begin{tabular}{lccc}
\hline Experimental field or population & $\begin{array}{c}\text { Total number of } \\
\text { plants evaluated }\end{array}$ & $\begin{array}{c}\text { Number of symptomatic } \\
\text { plants (\% of total) }\end{array}$ & $\begin{array}{c}\text { Number of plants with high or } \\
\text { severe symptoms }{ }^{\mathrm{a}}(\% \text { of total) }\end{array}$ \\
\hline PV1103 & 1,718 & $991(58 \%)$ & $200(12 \%)$ \\
PV1104 & 1,788 & $1,050(59 \%)$ & $436(24 \%)$ \\
PV0910 & 324 & $222(69 \%)$ & $60(20 \%)$ \\
Summer & 291 & $137(47 \%)$ & $22(8 \%)$ \\
K $\times$ S & 350 & $71(20 \%)$ & $1(<1 \%)$ \\
Kanlow & 356 & $80(22 \%)$ & $2(1 \%)$ \\
Kanlow N1 & 364 & $79(22 \%)$ & $3(1 \%)$ \\
Kanlow High Yield & & & \\
\hline
\end{tabular}

${ }^{a}$ Disease severity ratings of 4 or 5 . 
sampled and tested for PMV and SPMV in 2013. Less than 10\% of the sampled plants from Kanlow and the two Kanlow-derived populations were positive for PMV or PMV+SPMV (Fig. 2). In contrast, Summer and $\mathrm{K} \times \mathrm{S}$ populations had 66 and $36 \%$ of the sampled plants, respectively, infected with PMV alone or with $\mathrm{PMV}+\mathrm{SPMV}$. In both the Summer and $\mathrm{K} \times \mathrm{S}$ populations, nearly twice as many plants were infected with PMV+SPMV as were infected by PMV alone.

Together, these results reveal that the incidence of PMV and SPMV in 2013 varied among switchgrass populations. Summer and $\mathrm{K} \times \mathrm{S}$ appeared more prone to infection by PMV than populations derived from Kanlow. Furthermore, with the exception of infected plants in the Kanlow and Kanlow High Yield varieties, PMV was detected more often as a coinfection with SPMV than as a single infection.

Relationships between PMV and PMV+SPMV infection and disease severity. It is well established that PMV- and PMV+ SPMV-infected Brachypodium and Setaria host plants exhibit symptoms including chlorosis, necrosis, and stunting, and that coinoculation of those hosts with PMV and SPMV can result in heightened symptom expression over PMV alone (Mandadi and Scholthof 2012; Mandadi et al. 2014). However, it is not known whether such symptomology is recapitulated in PMV- and PMV+ SPMV-infected switchgrass plants under field conditions. Thus, we were interested in the relation between virus presence and disease symptom severity.

In 2013, randomly selected plants in PV1103, PV1104, and each of the five populations in PV0910 were sampled for virus presence and severity of virus-associated symptoms. Each plant was assigned a DSR (Table 1). The percentages of plants with no PMV, PMV alone, or PMV+SPMV within each DSR was examined. With few exceptions, sampled plants with DSRs of 3 or higher were infected by either PMV alone or PMV+SPMV. However, a portion of PMV- and PMV+SPMV-infected plants, from $1.7 \%$ (Kanlow High Yield) to $24.5 \%$ (Summer), were symptomless (Fig. 3 and Supplementary Table S3). With the exception of two plants $(\mathrm{K} \times \mathrm{S})$, DSRs of 4 and 5 were most often associated with plants that were coinfected with PMV and SPMV. Higher percentages of plants infected by PMV+SPMV, however, exhibited only mild to moderate symptoms (DSRs of 2 and 3, respectively). With the exception of one individual $(\mathrm{K} \times \mathrm{S})$, all plants infected with PMV alone were associated with DSRs of 3 or lower.

The data also was analyzed by comparing mean DSRs between three virus categories (no PMV, PMV only, PMV+SPMV) for each switchgrass population. In the PV0910 $\mathrm{K} \times \mathrm{S}$ population the mean DSR for plants infected by PMV alone was significantly higher
$(P=0.03)$ than plants with no PMV, but there was no significant difference in mean DSRs between plants infected by PMV+SPMV and plants with no PMV (Table 4). In contrast, analysis of results from PV1103, PV1104, and PV0910 Summer populations revealed the mean DSRs for plants with PMV+SPMV to be higher $(P<0.003)$ than the mean DSRs for plants with no PMV. The mean DSRs for plants with no PMV and for those with PMV alone were not significantly different in Summer in experimental field PV0910; there were no plants in PV1104 having PMV alone. In the comparison of mean DSRs for PMV alone with mean DSRs for PMV+SPMV, there was a significant difference only in Summer in PV0910, in which the mean DSR for plants infected with PMV+SPMV was higher than that of plants infected with PMV alone. Because of the low numbers of infected plants in the PV0910 Kanlow-derived populations, there were no significant effects of virus infection on DSRs in those populations.

Together, these results demonstrate that infection of switchgrass in the field by PMV and PMV+SPMV can lead to a range of DSRs. While the occurrence of virus symptoms under field conditions is closely related to infection by either PMV alone or PMV+SPMV, virus infection does not always lead to symptom expression. Furthermore, coinfection by PMV and SPMV does not always cause symptoms more severe than infection by PMV alone.

Year to year dynamics for PMV and SPMV. Switchgrass plants cultivated for bioenergy purposes are harvested annually for 8 to 10 years (McLaughlin and Kszos 2005; Vogel 2004). Thus, we were interested in determining the spread of PMV and SPMV and the persistence of these viruses in infected plants over annual harvest cycles. A subset of the sampled switchgrass individuals from two fields, PV1103 and PV1104, were assayed for PMV and PMV+ SPMV for two harvest years (2012 to 2013; 2013 to 2014). A third subset was resampled from PV0910 for one harvest year (2013 to 2014). Plants for the 2012 to 2013 resampling experiment were different plants than those selected for the 2013 to 2014 assays. Included in each set were plants that did not test positive for PMV in the previous year, those that tested positive for PMV alone, and those that tested positive for PMV+SPMV. The three sets were analyzed together, with a pooled total population of 102 plants. Among the 35 plants that previously did not test positive for the presence of PMV, 19 (54\%) remained PMV-free in the following year, three (9\%) tested positive for PMV alone, and $13(37 \%)$ tested positive for the presence of both PMV and SPMV (Table 5). Surprisingly of the 27 plants that previously tested positive for PMV alone, 11 (41\%) tested negative for the presence of either virus, and $16(59 \%)$ tested positive for PMV+SPMV. None of the plants tested positive for PMV alone in the next year. Lastly, most (90\%) of the 40 plants that

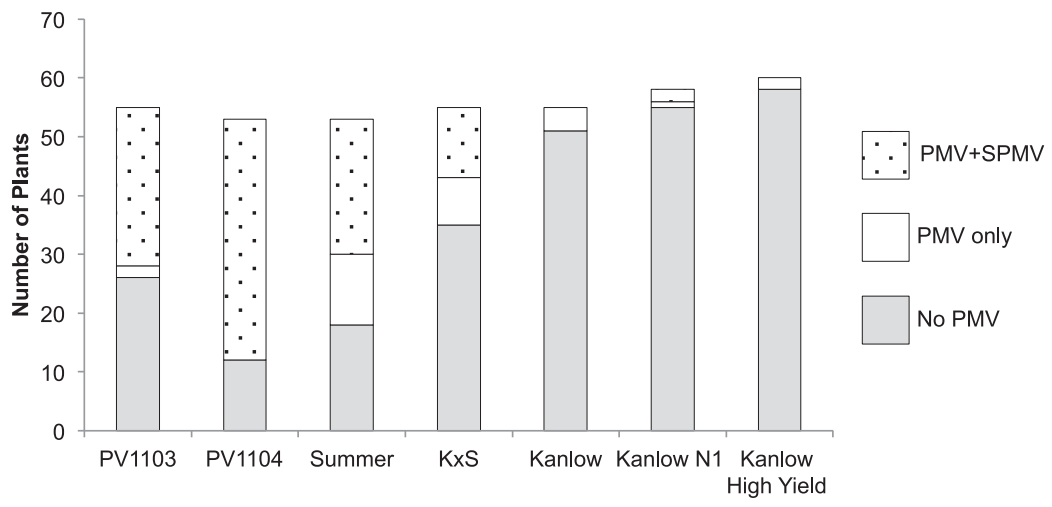

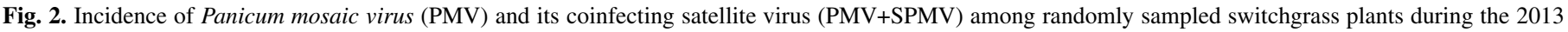

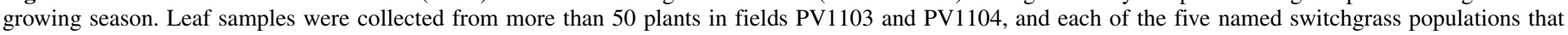

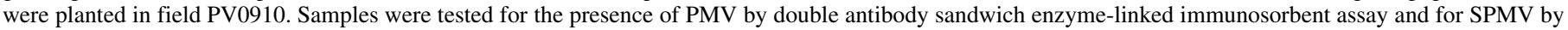
reverse transcription-polymerase chain reaction. 
previously tested positive for coinfection of PMV+SPMV remained positive for both viruses in the subsequent year, whereas only two plants were virus free or positive for PMV alone.

Taken together, these results indicate that PMV and PMV+SPMV can spread to new susceptible hosts between harvest cycles, and that those plants infected with both viruses will likely remain infected throughout future years of cultivation. It appears, however, that some plants infected only with PMV can become virus free over
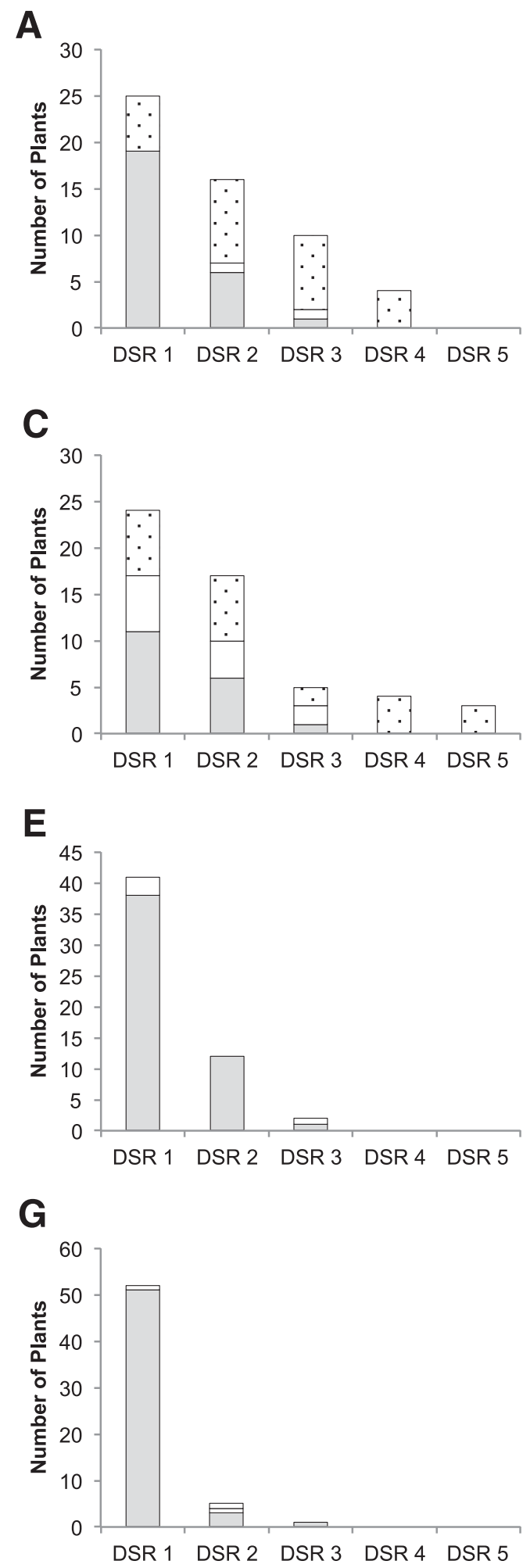

a single year, suggesting that the virus was below detectable levels or the plant may have cleared the virus infection.

\section{DISCUSSION}

PMV was first reported almost six decades ago in Kansas in switchgrass breeding plots with little attention to virus-infections since this initial finding. However, with switchgrass receiving

B

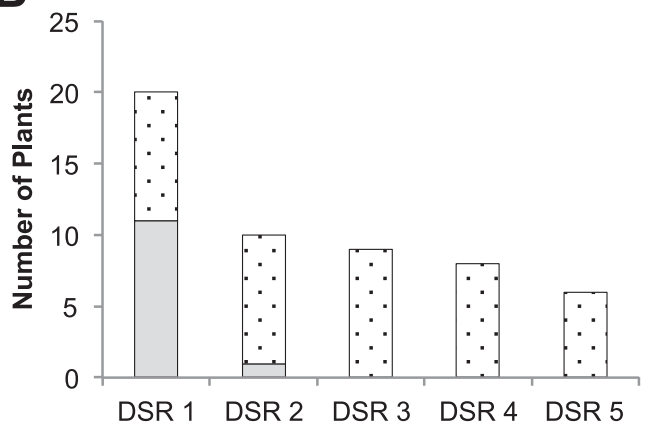

D

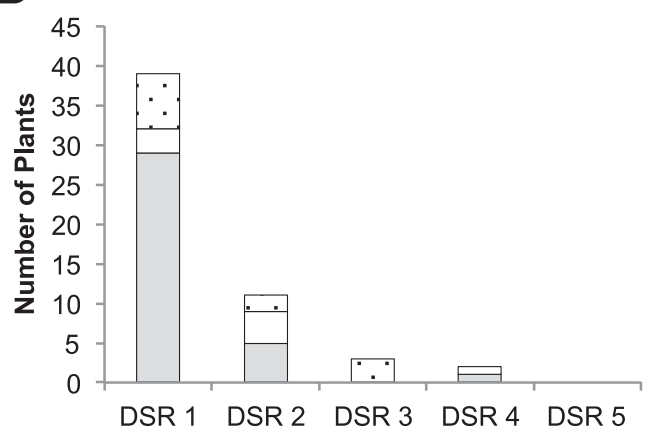

$\mathbf{F}$

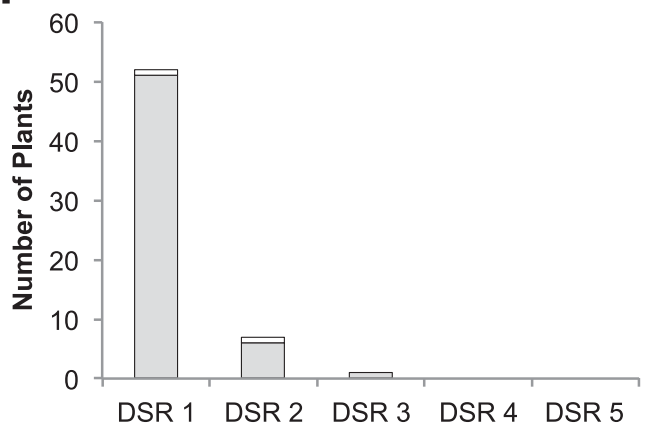

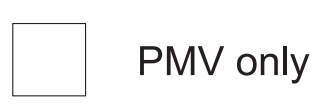

No PMV

Fig. 3. Relationship between presence of Panicum mosaic virus (PMV) and its coinfecting satellite virus (PMV+SPMV) and disease severity rating (DSR) of randomly sampled switchgrass in 2013. DSR 1 denotes no symptoms, while DSR 5 represents the highest symptom severity (Table 1). Individuals from fields A, PV1103, B, PV1104; and five populations in field PV0910: C, Summer, D, Kanlow $\times$ Summer $(\mathrm{K} \times$ S), E, Kanlow, F, Kanlow High Yield, and G, Kanlow N1. Absence of a data bar indicates that no plants were in that virus infection or DSR category. 
renewed attention in the 21 st century as a bioenergy crop, it is important to determine which pathogens are present and if they are negatively affecting plant health. Here, we report the first survey of multiple viruses in switchgrass from three established experimental breeding fields in Nebraska. From our investigations, we found a frequently observed association between virus-like symptoms and viral infections. The predominant viral pathogen present in these nurseries was PMV, either as a single infection or in a coinfection with its satellite virus and other viruses. This is the first report of coinfections of PMV+SPMV in cultivated switchgrass in the field. It also is the first report of PMV in coinfections with unrelated viruses in switchgrass hosts. The biological significance of these viral coinfection combinations, and any effects it has on switchgrass production, is an area that deserves further attention.

In 2012, switchgrass plants were specifically identified, sampled, and tested based on symptoms that are often associated with virus infection (e.g., chlorotic mosaic or mottling, stunting, or necrosis.). One limitation of the 2012 experimental design is that the symptomatic plants were only tested for six suspected viruses and SPMV. As a result, any additional viruses present in the symptomatic plants, and viruses that infected the switchgrass hosts without inducing symptoms, were not detected. The randomized sampling in 2013 was designed to provide an overall estimation of PMV and SPMV incidence for all three fields. It should be noted that these three breeding plots are not, and should not be treated as, representatives for all switchgrass populations. However, the variety of genetic backgrounds for the different switchgrass populations in the three nurseries investigated in this study allows for some conclusions to be drawn about the natural incidence of virus infections for diverse switchgrass varieties.

Although PMV was first identified as a pathogen of switchgrass in 1953 and in St. Augustinegrass a decade later, the virus has been primarily studied in the laboratory, with few follow-up field surveys (Batten and Scholthof 2004; Cabrera and Scholthof 1999; Sill and
Pickett 1957). Therefore, it was quite unprecedented to find PMV and SPMV as the predominant viral pathogens in switchgrass in this study. Several of the viruses identified in field samples are arthropod-transmitted (BYDV, CYDV, and SCMV). Arthropodtransmitted viruses are typically regarded as high-risk pathogens in agricultural settings due to their ability to spread quickly to new hosts over long distances (Jones 2006). SwMV, transmitted by the leafhopper Graminella aureovittata, may also be considered a risk (Agindotan et al. 2013c). In this study, we did not test for the presence of SwMV and, therefore, the involvement of SwMV in these switchgrass fields is unknown. Mechanical transmission is the only known mechanism for plant-to-plant spread of PMV and SPMV. It is likely that mechanical transmission of PMV and SPMV plays an important role in virus spread given the perennial nature of the crop as well as the procedures associated with switchgrass harvesting and maintenance (Vogel 2004).

Using a combination of random and targeted sampling approaches, we found that PMV alone and PMV+SPMV can spread to previously uninfected hosts in between harvest cycles. The coinfection of PMV+SPMV is more often detected together than PMV alone. Higher overall DSRs in the field are generally associated with PMV and PMV+SPMV infections across multiple genetically diverse switchgrass cultivars. Switchgrass populations Summer and $\mathrm{K} \times \mathrm{S}$ appeared to be more susceptible to infection by PMV or PMV+SPMV and more severe disease phenotypes were evident when compared with uninfected plants of the same cultivar.

In terms of viral pathogenesis and the unique PMV+SPMV disease synergism, it is interesting that PMV was found more often in a coinfection with SPMV in our random sampling of plants in breeding nurseries during the 2013 season than as a single infection (Fig. 2). The precise molecular advantages for PMV and SPMV to coexist within the host cell are still largely unknown. The striking synergistic disease symptoms associated with PMV+SPMV infections of other grasses suggests that this might have significant

TABLE 4. Mean disease severity ratings (DSR) among switchgrass plants with no virus detected, with Panicum mosaic virus (PMV) alone, and with PMV and its satellite virus (SPMV) ${ }^{\mathrm{a}}$

\begin{tabular}{|c|c|c|c|c|c|c|}
\hline \multirow[b]{2}{*}{ Experimental field or population } & \multicolumn{2}{|c|}{ No virus } & \multicolumn{2}{|c|}{ PMV alone } & \multicolumn{2}{|c|}{ PMV+SPMV } \\
\hline & Number of plants & Mean DSR & Number of plants & Mean DSR & Number of plants & Mean DSR \\
\hline PV1103 & 26 & 1.3 & 2 & $2.5^{*}$ & 27 & $2.4 * *$ \\
\hline PV1104 & 12 & 1.1 & nd & nd & 41 & $2.9 * *$ \\
\hline Summer & 18 & 1.4 & 12 & 1.7 & 23 & $2.5 * * \mathrm{~b}$ \\
\hline Kanlow $\times$ Summer $(\mathrm{K} \times \mathrm{S})$ & 35 & 1.2 & 8 & $1.9^{*}$ & 12 & 1.7 \\
\hline Kanlow & 51 & 1.3 & 4 & 1.5 & nd & nd \\
\hline
\end{tabular}

a Plants were randomly sampled in 2013 from two Nebraska breeding nurseries (PV1103 and PV1104) and from five switchgrass populations in experimental field PV0910. $*$ and $* *$ indicate significant difference from no virus at $P=0.05$ and 0.01 , respectively, based on comparison of least squares means (ls-means) using SAS ProcMixed. nd (no data) indicates an absence of plants in that category.

$\mathrm{b}$ indicates significant difference $(P=0.05)$ between 1s-means of PMV alone and PMV+SPMV.

TABLE 5. Annual change in the occurrence of Panicum mosaic virus (PMV) and its satellite virus (SPMV) in individual switchgrass plants

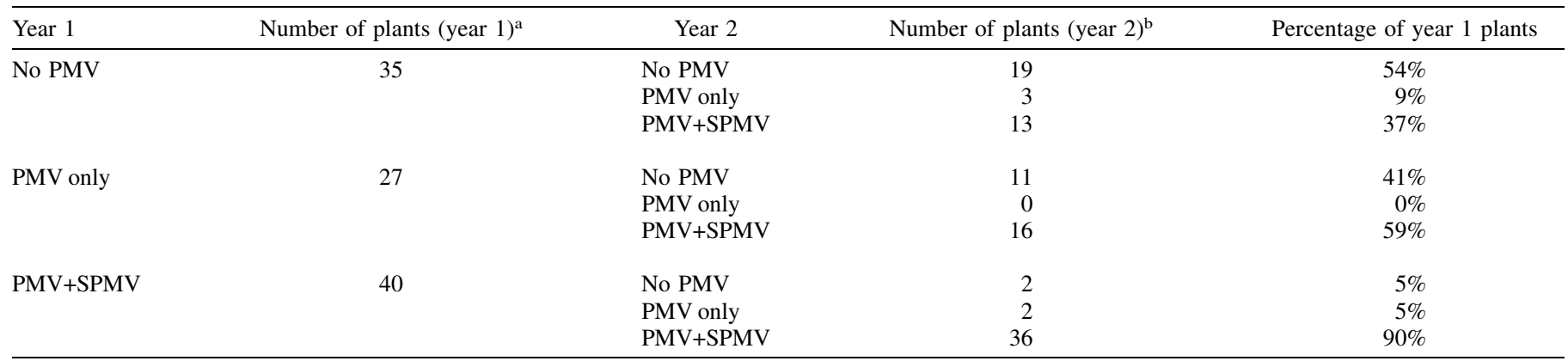

a Plants $(n=102)$ were selected based on their disease category (No PMV, PMV only, or PMV+SPMV) in year 1 (2012 or 2013).

b These plants were sampled for virus presence or absence in year 2 (2013 or 2014, respectively). 
negative implications for switchgrass production (Scholthof 1999), especially in a cropping system where a single perennial plant is expected to be productive for multiple years. A limitation of the current study is that the 2013 sampling data were only focused on the incidence of PMV and SPMV as specific causal agents of disease. As a result, we cannot determine whether or not the sampled plants in 2013 were infected with additional viruses. Plants that tested negative for PMV may have been infected with an additional virus(es) which may have influenced the DSR. Given the sampling results from 2012 (Table 3), a portion of the plants sampled in 2013 might be infected by additional viruses. However, due to the design of this project, these data are not available.

In our investigation of the temporal dynamics of infection by PMV and PMV+SPMV, a number of uninfected plants tested positive for PMV and SPMV in the following year (Table 5). It seems likely that the viruses spread to new hosts during the mechanical fall harvesting and spring cultivation processes (Vogel 2004). Additionally, it is possible that interactions between switchgrass roots in the soil can cause microabrasions in the root epidermal tissue that may allow for virus spread. Alternatively, a yet unidentified soilborne vector could spread the viruses. Previous experiments have demonstrated that certain Brachypodium accessions infected with PMV and SPMV accumulate higher titers of the viral CPs in the root tissues, compared with other infected accessions (J. D. Pyle and K-B. G. Scholthof, unpublished data). This would suggest that differences in host factors might allow for altered accumulation of virus particles or other viral complexes in the root tissues. However, there is currently no experimental evidence to support this mode of PMV or SPMV transmission. Given that switchgrass plants are expected to remain in the ground for sequential harvesting over the course of 8 to 10 years, it is important to consider the possible modes of transmission for viruses like PMV and SPMV, which could potentially account for widespread reductions in biomass yields in a matter of a few years.

In the same resampling study, other individuals that previously tested positive for PMV were negative for the virus when retested in the next year (Table 5). It is generally accepted that once a virus causes a systemic infection, the host plant will likely remain infected throughout the duration of its life. Therefore, one possible explanation for the absence of the virus in samples from previously infected plants is that PMV alone is less effective than PMV+SPMV in spreading systemically into the foliage from overwintering crown and root tissues. Additionally, we have previously observed that slight modifications to environmental conditions (e.g., day length, light intensity, and temperature) can result in altered accumulation of detectable viral CPs, specifically in the case of SPMV (Cabrera and Scholthof 1999; Mandadi and Scholthof 2012; Mandadi et al. 2014). However, there is the possibility that antiviral RNA silencing and other host-mediated defense responses may result in clearing of the virus infection (Alvarado and Scholthof 2009; Mandadi and Scholthof 2012; Mandadi et al. 2014). Additionally, we cannot rule out the possibility of experimental or sample error, which may have resulted in the lack of PMV detection in these samples. Currently, there is a lack of available information pertaining to systemic viral movement within infected switchgrass hosts. This information could clarify the significance of winterkill on systemic viral movement within the plant, and the potential ability of the host to clear the virus infection. The possible interactions between host, viral, and environmental factors may explain the unusual findings for the apparent virus clearing in year 2, presented in Table 5. Investigation of the potential factors involved may be important for our understanding of switchgrass antiviral responses and possible disease control mechanisms.

Another significant finding from this study pertains to the relationships that we identified between virus incidence, switchgrass cultivar, and increase in average DSR. Switchgrass varieties have been bred and selected for numerous desired traits and it is clear from the results of this study that some cultivars are more susceptible to virus infection than others. Our results indicate that the Kanlow parental variety may contain genomic features that confer tolerance against viral pathogens compared with populations with the Summer background. Segregation of the tolerance trait can be observed in the $\mathrm{K} \times \mathrm{S}$ switchgrass population that exhibited intermediate susceptibility and disease severity compared with the parent strains. The tolerance-imparting genetic loci in Kanlow against PMV should be investigated further as a possible parental resource for the development of switchgrass varieties that are less susceptible to the PMV disease complex, either through selective breeding methods or genetic engineering approaches.

Recent transcriptome analyses of field-grown Kanlow switchgrass revealed the upregulated expression of multiple WRKY transcription factors involved in pathogen response under field conditions, compared with the Summer variety (Palmer et al. 2014). Additionally, the gene expression levels for enzymes in the phenylpropanoid biosynthesis pathway, and accumulation of their downstream metabolite products are higher in the Kanlow cultivar compared with Summer (Palmer et al. 2014). Overall, the results from transcriptomic and metabolomic analyses suggests that Kanlow may be primed for defense against invading pathogens, including viruses, compared with the Summer cultivar.

These genetic differences in switchgrass types in response to virus infection suggest that in the future particular attention should be paid to Kanlow and other lowland germplasm as viable solutions toward improving the performance of switchgrass as a bioenergy crop. This study provides the first framework for our understanding of major viral pathogen problems for cultivated switchgrass and reveals PMV and PMV+SPMV as agents of concern for pathogenassociated losses in the field and reduced production efficiency for biofuel applications.

\section{ACKNOWLEDGMENTS}

Funding for C. L. Stewart, C. Jochum, K. Vogel, and G. Y. Yuen was provided in part by the CenUSA Bioenergy project supported by Agriculture and Food Research Initiative Competitive Grant 2011-6800530411 from the USDA National Institute of Food and Agriculture. This study also was supported in part by undergraduate and graduate research fellowships from the American Society for Microbiology and Texas A\&M University awarded to J. D. Pyle. We thank P. Goodin, E. Kruse, A. Mueller, and L. Stang for field and laboratory technical assistance. We appreciate the critical comments and helpful discussions provided by H. B. Scholthof and K. K. Mandadi during manuscript preparation. Mention of trade names or commercial products in this publication does not imply recommendation or endorsement by the U.S. Department of Agriculture.

\section{LITERATURE CITED}

Agindotan, B. O., Ahonsi, M. O., Domier, L. L., Gray, M. E., and Bradley, C. A. 2010. Application of sequence-independent amplification (SIA) for the identification of RNA viruses in bioenergy crops. J. Virol. Methods 169: 119-128.

Agindotan, B. O., Domier, L. L., Gray, M. E., and Bradley, C. A. 2013a. Eight new viruses identified in bioenergy switchgrass. (Abstr.) Phytopathology 103(suppl.):S2.3.

Agindotan, B. O., Okanu, N., Oladeinde, A., Voigt, T., Long, S., Gray, M., and Bradley, C. 2013b. Detection of Switchgrass mosaic virus in Miscanthus and other grasses. Can. J. Plant Pathol. 35:81-86.

Agindotan, B. O., Prasifka, J. R., Gray, M. E., Dietrich, C. H., and Bradley, C. A. 2013c. Transmission of Switchgrass mosaic virus by Graminella aureovittata. Can. J. Plant Pathol. 35:384-389.

Alvarado, V., and Scholthof, H. B. 2009. Plant responses against invasive nucleic acids: RNA silencing and its suppression by plant viral pathogens. Semin. Cell Dev. Biol. 20:1032-1040.

Batten, J., and Scholthof, K.-B. G. 2004. St. Augustine decline. Pages 800-802 in: Viruses and Virus Diseases of Poaceae (Gramineae). H. Lapierre and P. Signoret, eds. INRA, Paris.

Bouton, J. H. 2007. Molecular breeding of switchgrass for use as a biofuel crop. Curr. Opin. Genet. Dev. 17:553-558.

Cabrera, O., and Scholthof, K.-B. G. 1999. The complex viral etiology of St. Augustine decline. Plant Dis. 83:902-904. 
Carris, L. M., Castlebury, L. A., and Zale, J. 2008. First report of Tilletia pulcherrima bunt on switchgrass (Panicum virgatum) in Texas. Plant Dis. 92:1707.

Cassida, K. A., Kirkpatrick, T. L., Robbins, R. T., Muir, J. P., Venuto, B. C., and Hussey, M. A. 2005. Plant-parasitic nematodes associated with switchgrass (Panicum virgatum L.) grown for biofuel in the south central United States. Nematropica 35:1-10.

Crouch, J. A., Beirn, L. A., Cortese, L. M., Bonos, S. A., and Clarke, B. B. 2009. Anthracnose disease of switchgrass caused by the novel fungal species Colletotrichum navitas. Mycol. Res. 113:1411-1421.

Etheridge, J. V., Davey, L., and Christian, D. G. 2001. First report of Rhizoctonia cerealis causing sharp eyespot in Panicum virgatum in the UK. Plant Pathol. 50:807.

Garrett, K. A., Dendy, S. P., Power, A. G., Blaisdell, G. K., Alexander, H. M., and McCarron, J. K. 2004. Barley yellow dwarf disease in natural populations of dominant tallgrass prairie species in Kansas. Plant Dis. 88:574.

Gray, S., and Gildow, F. E. 2003. Luteovirus-aphid interactions. Annu. Rev. Phytopathol. 41:539-566.

Hill, J., Nelson, E., Tilman, D., Polasky, S., and Tiffany, D. 2006. Environmental, economic, and energetic costs and benefits of biodiesel and ethanol biofuels. Proc. Natl. Acad. Sci. USA 103:11206-11210.

Jones, R. A. C. 2006. Control of plant virus diseases. Adv. Virus Res. 67: 205-244.

Krupinsky, J. M., Berdahl, J. D., Schoch, C. L., and Rossman, A. Y. 2004. Leaf spot on switchgrass (Panicum virgatum), symptoms of a new disease caused by Bipolaris oryzae. Can. J. Plant Pathol. 26:371-378.

Mandadi, K. K., Pyle, J. D., and Scholthof, K.-B. G. 2014. Comparative analysis of antiviral responses in Brachypodium distachyon and Setaria viridis reveals conserved and unique outcomes among C3 and C4 plant defenses. Mol. Plant-Microbe Interact. 27:1277-1290.

Mandadi, K. K., and Scholthof, K.-B. G. 2012. Characterization of a viral synergism in the monocot Brachypodium distachyon reveals distinctly altered host molecular processes associated with disease. Plant Physiol. 160: 1432-1452.

Masuta, C., Zuidema, D., Hunter, B. G., Heaton, L. A., Sopher, D. S., and Jackson, A. O. 1987. Analysis of the genome of satellite panicum mosaic virus. Virology 159:329-338.

McLaughlin, S. B., and Kszos, L. A. 2005. Development of switchgrass (Panicum virgatum) as a bioenergy feedstock in the United States. Biomass Bioenergy 28:515-535.

Mekete, T., Reynolds, K., Lopez-Nicora, H. D., Gray, M. E., and Niblack, T. L. 2010. Plant-parasitic nematodes are potential pathogens of Miscanthus $\times$ giganteus and Panicum virgatum used for biofuels. Plant Dis. 95:413-418.
Palmer, N. A., Saathoff, A. J., Tobias, C. M., Twigg, P., Xia, Y., Vogel, K. P., Madhavan, S., Sattler, S. E., and Sarath, G. 2014. Contrasting metabolism in perenniating structures of upland and lowland switchgrass plants late in the growing season. PLoS One 9:e105138.

Perry, A. 2012. Biofuel prospects with prairie perennials. Agric. Res. Mag. 60: 7-9.

Sanderson, M. A., Reed, R. L., McLaughlin, S. B., Wullschleger, S. D., Conger, B. V., Parrish, D. J., Wolf, D. D., Taliaferro, C., Hopkins, A. A., Ocumpaugh, W. R., Hussey, M. A., Read, J. C., and Tischler, C. R. 1996. Switchgrass as a sustainable bioenergy crop. Bioresour. Technol. 56:83-93.

Schmer, M. R., Vogel, K. P., Mitchell, R. B., and Perrin, R. K. 2008. Net energy of cellulosic ethanol from switchgrass. Proc. Natl. Acad. Sci. USA 105:464-469.

Scholthof, K.-B. G. 1999. A synergism induced by satellite panicum mosaic virus. Mol. Plant-Microbe Interact. 12:163-166.

Sill, W. H., and Pickett, R. C. 1957. A new disease of switchgrass, Panicum virgatum. Plant Dis. Rep. 41:241-249.

Somma, D., Lobkowicz, H., and Deason, J. 2010. Growing America's fuel: An analysis of corn and cellulosic ethanol feasibility in the United States. Clean Tech. Environ. Policy 12:373-380.

Thomas, J. E., and Steele, V. 2011. First report of Panicum mosaic virus in buffalo grass (Stenotaphrum secundatum) from Australia. Australas. Plant Dis. Notes 6:16-17.

Tiffany, L. H., and Knaphus, G. 1995. Fungus pathogens of prairie plants in Iowa. Pages 49-54 in: 14th Annual North American Prairie Conference. Kansas State University, Manhattan, KS.

Turina, M., Desvoyes, B., and Scholthof, K.-B. G. 2000. A gene cluster encoded by Panicum mosaic virus is associated with virus movement. Virology 266:120-128

Turina, M., Maruoka, M., Monis, J., Jackson, A. O., and Scholthof, K.-B. G. 1998. Nucleotide sequence and infectivity of a full-length cDNA clone of Panicum mosaic virus. Virology 241:141-155.

Uppalapati, S. R., Serba, D. D., Ishiga, Y., Szabo, L. J., Mittal, S., Bhandari, H. S., Bouton, J. H., Mysore, K. S., and Saha, M. C. 2013. Characterization of the rust fungus, Puccinia emaculata, and evaluation of genetic variability for rust resistance in switchgrass populations. Bioenerg. Res. 6:458-468.

Vogel, K. P. 2004. Switchgrass. Pages 561-588 in: Warm-Season (C4) Grasses. L. E. Moser, B. L. Burson, and L. E. Sollenberger, eds. American Society of Agronomy, Crop Science Society of America, Soil Science Society of America. Madison, WI.

Vu, A. L., Dee, M. M., Gualandi, R. J., Huff, S., Zale, J., Gwinn, K. D., and Ownley, B. H. 2011. First report of leaf spot caused by Bipolaris spicifera on switchgrass in the United States. Plant Dis. 95:1191. 